\title{
Land resource analysis in Jakarta Special Province, Indonesia
}

\author{
Kurniasari ${ }^{1}$, Dewina Inggar Santi $^{1}$, Laelina Rahmawati $^{1}$, Dzakwan Taufiq Nur Muhammad ${ }^{1}$, Agung Laksono ${ }^{1}$, \\ Wisha Puti Maulidina ${ }^{1}$, Ratih Fitria Putri $^{{ }^{*}}$, Rika Harini ${ }^{1}$, and Josaphat Tetuko Sri Sumantyo ${ }^{2}$
}

${ }^{1}$ Department of Environmental Geography, Faculty of Geography, Universitas Gadjah Mada, Indonesia

${ }^{2}$ Center for Environmental Remote Sensing, Chiba University, Japan

\begin{abstract}
The increasing number of Jakarta Special Province residents further increased the amount of land required for daily usages. In order to maintain and improve the economy, agricultural land-use continued to be converted into non-agricultural land-use. The reduced amount of agricultural land-use was able to increase the population pressure on said land, surpassing the land carrying capability. Analyzing the remaining land resources of Jakarta Special Province aimed to understand the changes in land-use, land carrying capability, the scale of land resources, and to determine the population pressure of the residents of Jakarta Special Province. The methods used in this analysis was to use secondary data, presented in the form of tables, graphs, and maps, as well as quantitative and qualitative descriptive analysis. In general, Jakarta Special Province had experienced a conversion of agricultural land-use into non-agricultural land-use (e.g. residential and industrial) between the year 2010 to 2018 . The number of residents had exceeded the carrying capacity of Jakarta's land. This resulted from a growing need for non-agricultural land as well as the amount of population pressure, causing the unmet settlement needs.
\end{abstract}

\section{Introduction}

The definition of land-use is all forms of land change affected by human activities to meet their needs [1]. The core of land carrying capability is to compare between demand and supply. Demand means the desire or needs for someone to obtain an item or a service; supply means the number of goods and/or services available [2]. The land is a limited natural resource; whilst human needs are infinite and will continue to increase, following the population growth. Jakarta's residents experience growth every year as indicated by the conversion of agricultural land to non-agricultural land, to fulfill the needs of industrial development, housing, tourism, and other purposes. Land change tends to have a permanent nature due to the inability of converted non-agricultural land to be reused as before [3]. Land change is related to the land's carrying capacity, which can be determined based on the value of population pressure and the scale of land resources. Areas with high population pressure are incapable of supporting the needs of the residents living there.

According to [4] the amount of open green space in Jakarta Special Province does not meet the required standards, and only about $10 \%$ of the area is left for development. This shows that almost all areas in Jakarta have been developed; most of the development was to change agricultural lands to non-agricultural. Based on this, the population pressure was raised and will further impact the land's productivity. A high population pressure equals the low productivity of agricultural land [5], meaning that agricultural production will be lower. Other than that, land productivity is influenced by the carrying capacity of land; a low land carrying capacity means low productivity. The impact of land productivity, especially agricultural land, is Jakarta Special Province being unable to meet the basic needs of agricultural products demanded by its population. Jakarta Special Province still relies on its food supply from other regions such as Banten, West Java, Central Java, and Java [6].

Landuse change will also affect the land carrying capacity; if the land carrying capacity has been exceeded, it will cause various problems such as the land becoming critical and even natural disasters such as floods. Based on these explanations, it is important to analyze land resources, particularly in Jakarta Special Region.

This research aims to achieve include:

1. Analyzing land-use changes occurring in Jakarta Special Province

2. Analyzing land carrying capacity in Jakarta Special Province

3. Analyzing the scale of active and passive land resources available in Jakarta Special Province

4. Understanding the amount of population pressure on land in Jakarta Special Province.

Based on those objectives, this research can be used as a medium of information regarding the intensive land changes and land carrying capacity in Jakarta Special Province and can be considered in determining future solutions

\footnotetext{
${ }^{*}$ Corresponding author: ratihfitria.putri@ugm.ac.id
} 


\section{Methods}

The method used in the analyzing process is a descriptive method using secondary data. The type of analysis used is a quantitative and qualitative description. The data results are shown in the form of tables, graphs (to show the temporal pattern), and maps (to show the spatial pattern). The calculation formula used for each indicator are as follows:

\subsection{Population Pressure}

Population pressure is the ratio between the number of residents and the minimum land required to live properly [7]. Population pressure can be calculated using three methods, namely population pressure model I, population pressure model II, and population pressure model III [8].

\subsubsection{Model I}

The model I consider that the population only lives on cultivated agricultural land.

$$
T p=Z \frac{f P o(1+r)^{t}}{L}
$$

\subsubsection{Model II}

Model II added income factors from the non-agricultural sector.

$$
T p=Z(1-\alpha) \frac{f P_{o}(1+r)^{t}}{L}
$$

\subsubsection{Model III}

Model III adds value factors of land benefits for farmers.

$$
T p=Z(1-\alpha) \frac{f P o(1+r)^{t}}{\beta L_{t o t}}
$$

Information:

$\mathrm{Tp}=$ Population Pressure

$\mathrm{Z}=$ Land area needed to support the life of a farmer to live properly

$\mathrm{f}=$ farmers percentage in the population

$\mathrm{Po}=$ total population in the base year

$\mathrm{r}=$ population growth

$\mathrm{t}=$ year

$\mathrm{L}=$ agricultural land size area

$\alpha=$ income factor from nonagricultural land

$\beta=$ factor value of land benefits for farmers

\subsection{Land Carrying Capability}

Land carrying capability is one of the many forms of land capability related to fulfilling human needs [9]. The formula used is as follows:

$$
\mathbf{A}=\mathbf{L} / \mathbf{P}
$$

Information:

A $=$ land carrying capability

$\mathrm{L}=$ land area size

$\mathrm{P}=$ number of inhabitants

\subsection{Balance of Natural Resources}

The natural resource balance is used to determine the balance between the availability of the land, the land-use needs, and the land-use of a certain area, created using data taken twice a year [10]. The flowchart below explains the steps used to analyze the Land Resources of Jakarta Special Province Province:

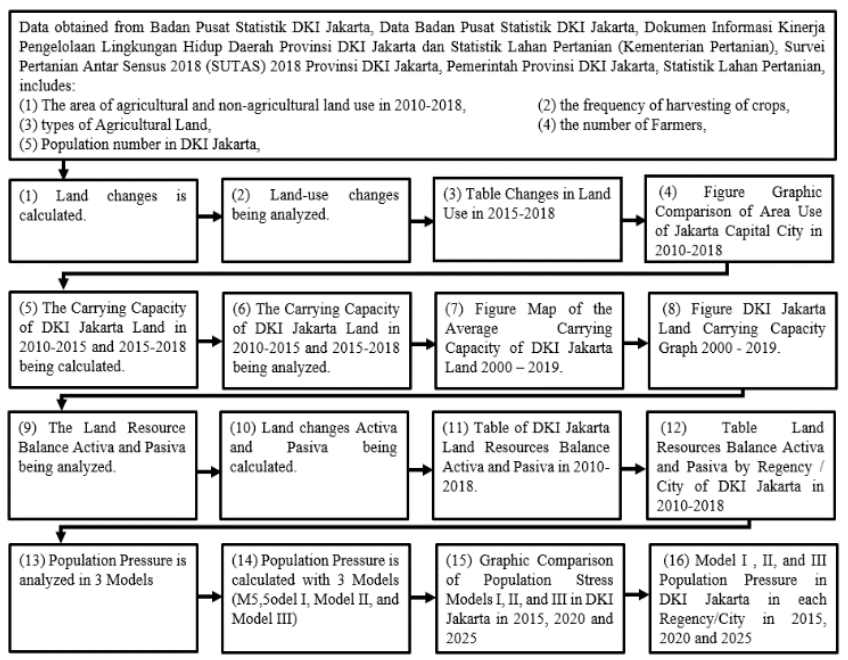

Fig. 1. Flow chart of the analysis of land resources

\section{Discussion}

\subsection{Land Use Change}

Jakarta Special Province as the center of Indonesia's economic activity promoted the province as a destination of population movements from areas outside the province, causing the population to increase. The record taken in 2018 showed Jakarta Special Province's population grew by $1,07 \%$ [11]. An increase in population further increased the needs of economy and development, impacting the physical environment especially in land-use changes. Based on the Jakarta Special Province Regional Spatial Plan for 2010 - 2030, this region had an area of 6623 hectares, dominated by non-agricultural land-use.

Comparison of land-use from 2010-2018 in Figure 2. showed a fluctuating trend but always dominated by non-agricultural land-use.

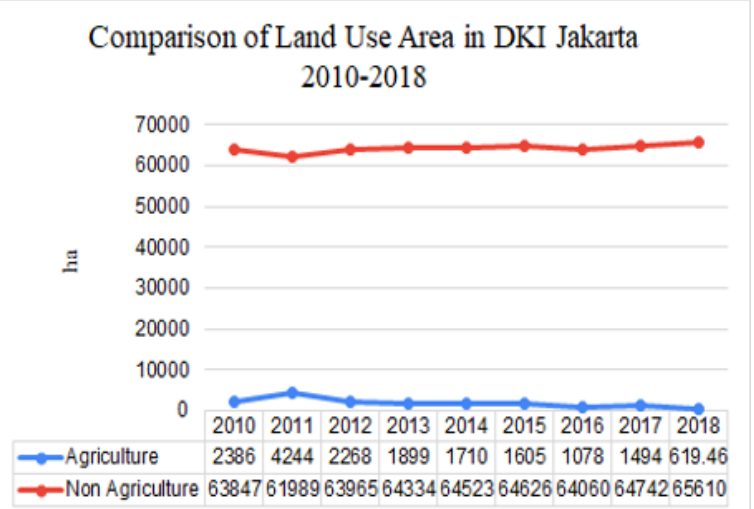

Fig. 2. Comparison of Agriculture \& Non-Agriculture Area 2010 - 2018. Source: Ministry of Agriculture 
The pattern of land-use changes between 2010 - 2015 and 2015-2018 shown in Table 1 depicted a similarity regarding the decreasing number of agricultural land areas and the increasing number of residential and industrial land areas.

Table 1. Land-use changes in Jakarta 2010-2018

\begin{tabular}{|c|c|c|c|c|c|c|}
\hline \multicolumn{2}{|c|}{ Land Use } & \multicolumn{3}{|c|}{ Land Area (Ha) } & \multicolumn{2}{|c|}{ Changes } \\
\hline & & 2010 & 2015 & 2018 & 2010-2015 & 2015-2018 \\
\hline \multirow[b]{2}{*}{ AGRICULTURE } & Paddy field & 1312 & 650 & 232.57 & -662 & $-417,43$ \\
\hline & $\begin{array}{c}\text { Dry land } \\
\text { agriculture }\end{array}$ & 1209 & 955 & 386,89 & -254 & $-568,11$ \\
\hline \multirow{6}{*}{$\begin{array}{c}\text { NON } \\
\text { AGRICULTURE }\end{array}$} & Settlement & 1256,75 & 57844 & 58700 & $\begin{array}{r}+56587,25 \\
\end{array}$ & +856 \\
\hline & Fishery & 106.43 & 125 & 128 & +18.57 & +3 \\
\hline & Forestry & 639,84 & 1101 & 1101 & $+461,16$ & 0 \\
\hline & Industry & 3908 & 4032.37 & 4572 & $+124,37$ & 539,63 \\
\hline & Water body & 2002,01 & 1524 & 1109 & $-478,01$ & -415 \\
\hline & Open land & 0 & 80 & 147 & +80 & +67 \\
\hline
\end{tabular}

\subsection{Land Carrying Capacity}

The carrying capacity of land was analyzed to determine the ability of the land to support human livelihoods, including human activities done on it [12]. The assessment of land carrying capacity can be used as a basis for policymaking, regional planning, and other strategic policies. Land carrying capacity under a geographical perspective can be analyzed spatially or temporally.

Jakarta Special Province's spatial land carrying capacity based on Table 2. and Figure 3. showed how from the year 2000 to 2019, all the cities in Jakarta Special Province had exceeded the land carrying capacity.

Table 2. Land carrying capacity in Jakarta Special Province

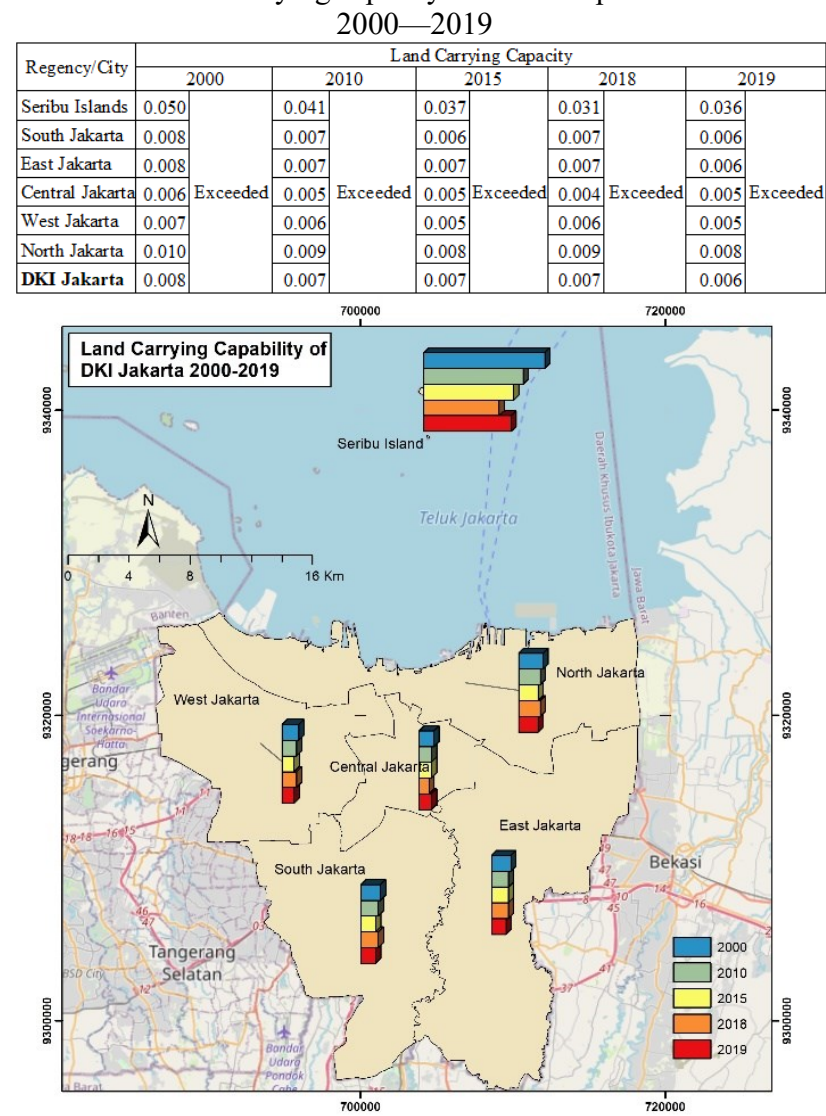

Fig. 3. Land Carrying Capacity of Jakarta Special Province Province 2000-2019
The results showed that the population in Jakarta Special Province had exceeded the capacity of the land accommodating human activities, in other words, based on the classification the land was no longer able to provide sufficient space for humans [13]. This condition of Jakarta Special Province was caused by its status as Indonesia's center of government and economy, as it invited immigrants from other regions to come to this region in hopes of obtaining a better economic status than their area of origin. Moreover, based on data [14] Jakarta Special Province was the only province to have a regional minimum wage (Upah Minimum Regional/UMR) above IDR 3 million in 2016, making Jakarta Special Province the province with the higher UMR in Indonesia. This good economic condition made a lot of residents from other regions move to Jakarta Special Province to try their luck in obtaining a better social and economic status. The impact of this was a reducing ability of the land carrying capacity to support the activities of the residents living on it.

Jakarta Special Province is located at 0-100 mdpl with a slope of $0-7 \%$. Almost all regions in Jakarta Special Province were grouped into Van Zuidam's 1985 classification as flat [15]. Most of the land is flat and was formed by fluviomarine activities, creating a lot of choices to determine the correct land-use for Jakarta Special Province. This advantage was turned into a disaster for this region because the most commonly selected land-use was for non-agricultural land-use, such as industrial and settlement. This condition was caused because developing non-agricultural land-use brought more profit compared to other land-uses. The Jakarta Special Province today had understood that its land can no longer accommodate a high amount of population; therefore, its government, together with private sectors provided a solution in the form of "Vertical Housing" to overcome the problem of the lack of available land for settlements. There were a lot of apartments built in Jakarta Special Province to engineer the carrying capacity of the remaining land to provide sufficient space for the residents. This engineering was carried out because based on Yeates et al.'s opinion [13], it's better to utilize land vertically and not horizontally to support human activities. Providing sufficient space for humans vertically coupled with the presence of improving technology resulted in human activities not only relying on the agricultural sector but also the service sector; whom with relatively small land were able to produce human resources of good quality and high productivity. The large number of residents who work in the service sector can overcome the problem of space so that people can do daily activities and still benefit economically.

The temporal land carrying capacity of Jakarta Special Province was shown in Figure 4, depicting the relationship between population and land area both the actual state and the recommended state. Based on the said graph, the population of Jakarta Special Province had exceeded its carrying capacity for 20 years based on Yeates et al. 's classification. This can be seen in the number of residents who should be in Jakarta Special Province (shown in green) based on the existing land area. The area of land had not changed for years, making the 
population growth the only cause of Jakarta Special Province's land carrying capacity being exceeded. It can be seen in the graph that the population in Jakarta Special Province currently exceeds 15 times the amount of population that should exist, based on the land's carrying capacity.

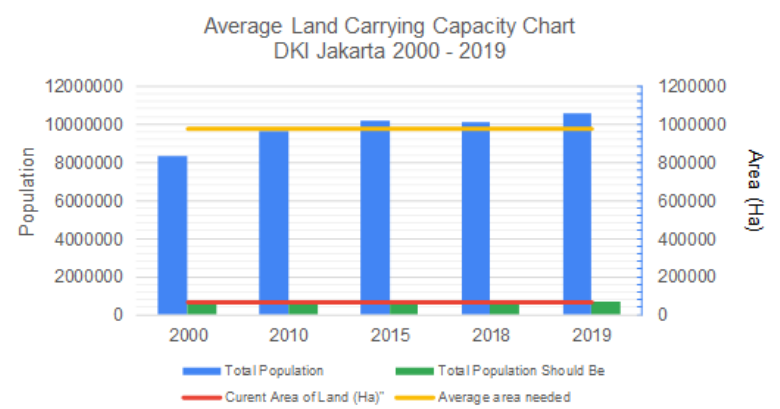

Fig. 4. Average Land Carrying Capacity Jakarta Special Province 2000-2019

The always growing population versus the fixed amount of land became a challenge for Jakarta Special Province to overcome. Yellow lines in the figure explained the area of land that should be owned by the province with its current population number. However, this condition was unable to be achieved especially since the land needed must be at least 14 times bigger than the current land area. The reclamation carried in Teluk Jakarta had not been able to overcome the land problem. Therefore, "Vertical Housing" became a solution in overcoming the carrying capacity of the land being unable to provide enough space for its residents. Provision of vertical space made the limited amount of land can be used optimally.

"Vertical Housing", while providing a good solution for the increasing population, can't be the only solution for the said problem. Therefore, another solution must be sought. This isn't related only to the provision of space, but also the provision of basic human needs and equality. A large amount of the population increased the number of needs demanded by the community. If the region was unable to provide sufficient supply, then problems such as poverty, inequality, and other welfare problems are most likely going to rise in Jakarta Special Province. Therefore, population control through family planning, contraception methods, and so on became important in Jakarta Special Province.

\subsection{Land Resources Balance}

Jakarta Special Province's resource balance was done with asset (active) and liability (passive) approach, using a reserved approach and the potential for agricultural and non-agricultural land-use. In 2010 the asset of nonagricultural land use was 63,847 hectares wide $(96 \%)$ and agricultural land-use was 2,386 hectares wide (4\%). Meanwhile, in 2018 the liabilities of non-agricultural land-use are 65,610 hectares wide (99\%) and agricultural land-use is 620 hectares wide (1\%). The number of assets (2010) and liability (2018) land resources showed in Table 1.
Non-agricultural land-use which experienced the most reduction was inland water (-893 hectares) in the form of swamps and rivers; while the most reduced agricultural land was paddy fields $(-1,079$ hectares) (Shows in Figure $5)$. The decline in agricultural land-use was caused by the conversion of land into non-agricultural land. Such things were able to be known because residential land-use raised by 57,442 hectares, followed by industrial growth. The increase in the industrial area will cause economic growth but will impact the environment negatively. Besides, the increasing number of settlements caused a high population density, triggering slum areas that are identical to poverty. In Jakarta Special Province there were 181 urban villages out of 267 urban villages in 1.024,52 hectares wide area included in the slum category, among which is the highest in West Jakarta region [16].

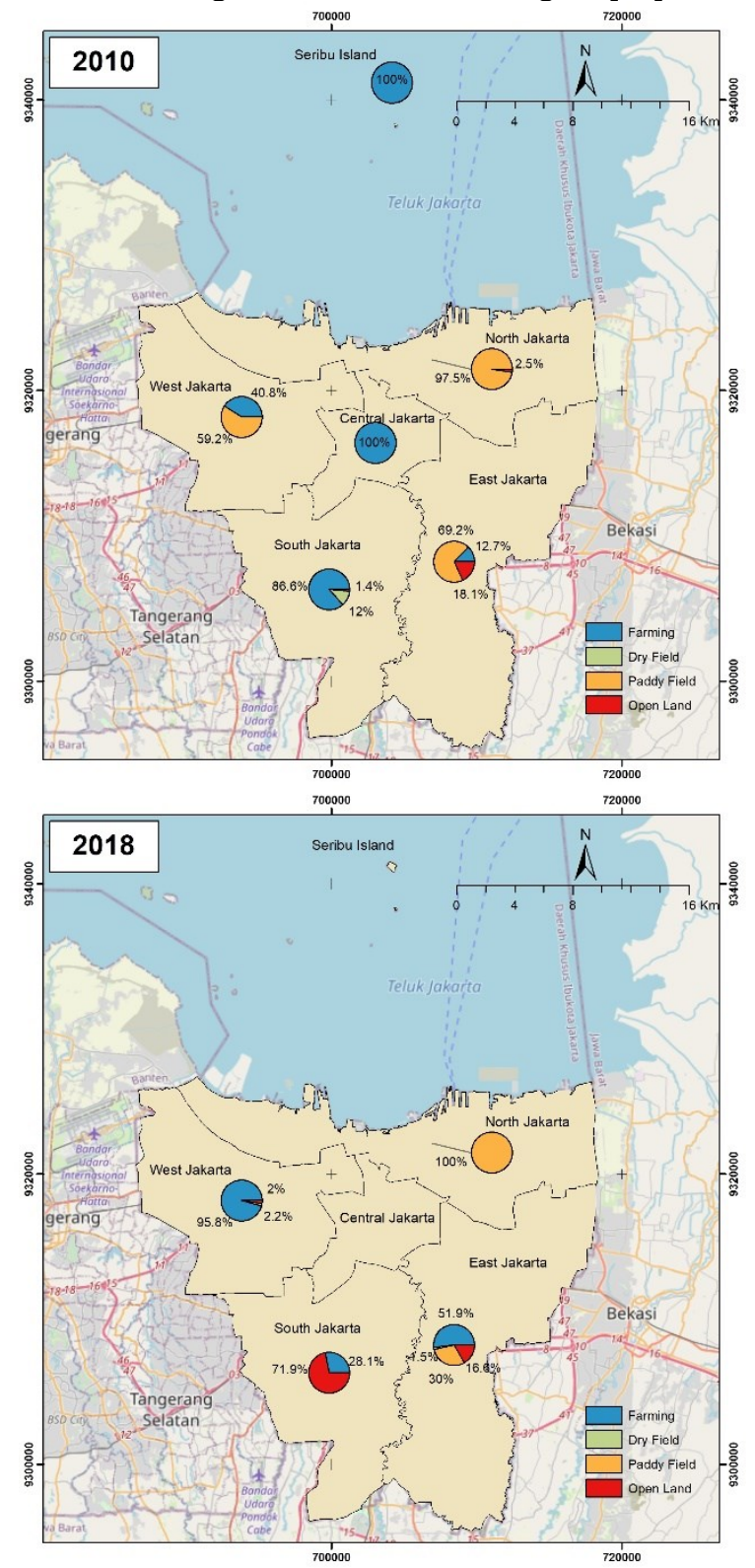

Fig. 5. Agricultural land balance in Jakarta Special Province 2010 and 2018. In 2018, Central Jakarta and Seribu Island regency haven't agricultural land. Source: Ministry of Agriculture

The scale of land resources in Jakarta Special Province's regency and city level showed that for 9 years 
there had been a decrease in paddy field areas. Changes in paddy fields occurred in regency/cities with paddy fields, namely North Jakarta, West Jakarta, and East Jakarta. Meanwhile, in the cities of East Jakarta and West Jakarta, there was an increase in the area of dry fields.

The size of the vacant area in South Jakarta was smaller in the assets year than in the liability year, meaning that there had been an increase in vacant land in South Jakarta. The reason why the agricultural land-use in Jakarta Special Province has a very small amount was that most of the economy was supported by the service sector and industry sector. Based on BPS's data in 2015, the agricultural sector only contributed $0.09 \%$ to the provincial GRDP (PDRB. In the end, most of the area functioned as industrial and settlements, not for agricultural purposes. This was supported by the number of active farmers in East Jakarta and West Jakarta, with the total number of farmers in Jakarta Special Province reaching 16,939 people in 2018 [17].

The small amount of agricultural land caused food production to below, as well as causing food needs in Jakarta Special Province being unable to be fulfilled. This caused food dependency to other provinces such as Central Java and West Java, or from international imports. Jakarta Special Province's government's effort to reduce food dependency was to implement the Urban Farming program. Urban Farming applied a system of growing foodstuffs planted on open land [18]. This program provided an opportunity for the community to plant seedlings using the remaining land between settlement alleys with consumable plants such as vegetables, chilies, and fruits. Not only that, to minimize settlement land needs the KOTAKU program was created to help develop slum areas so that poverty can be reduced and those areas can be more productive.

\subsection{Population Pressure}

The results of the calculation of population pressure in the Jakarta Special Province using three models showed different results. That was caused by the different factors used in each model. Comparison graphs of the three population pressure models are shown in these following figures:

\begin{tabular}{|c|c|c|c|}
\hline \multicolumn{4}{|c|}{$\begin{array}{l}\text { Graphic Comparison of Population Pressure } \\
\text { Models I, II, and III in DKI Jakarta in 2015, } \\
2020 \text {, and } 2025\end{array}$} \\
\hline \multirow{3}{*}{$\begin{array}{l}16000,00 \\
14000,00 \\
12000,00 \\
10000,00\end{array}$} & \multirow{2}{*}{12929,68} & \multirow[t]{2}{*}{13650,59} & \multirow[t]{2}{*}{14411,71} \\
\hline & & & \\
\hline & 7956,72 & 8400,36 & 8868,74 \\
\hline $\begin{array}{ll}\text {. } & 8000,00 \\
\text { 总 } & 6000,00\end{array}$ & 5171,87 & 5460,24 & 5764,68 \\
\hline \multirow{2}{*}{$\begin{array}{l}6000,00 \\
4000,00 \\
2000,00\end{array}$} & & & \\
\hline & & & \\
\hline 0,00 & & 2020 & 2025 \\
\hline$\multimap$ Model I & $\mathrm{TP}>1$ & $\mathrm{TP}>1$ & $\mathrm{TP}>1$ \\
\hline$\multimap$ Model II & $\mathrm{TP}>1$ & $\mathrm{TP}>1$ & $\mathrm{TP}>1$ \\
\hline$\rightarrow$ Model III & $\mathrm{TP}>1$ & $\mathrm{TP}>1$ & $\mathrm{TP}>1$ \\
\hline
\end{tabular}

Fig. 6. Graphic comparison of population pressure models I, II, and III in Jakarta Special Province 2015, 2020, and 2025.
Figure 6 showed that Model III had the highest results compared to Model I and II. This proved that the benefits of agricultural land in Jakarta Special Province continued to decline from year to year, causing a growing population pressure. This decline in benefits was caused due to the conversion of agricultural land to non-agricultural land in Jakarta Special Province. The agricultural land area had decreased by 985 ha [19]. The smaller agricultural land area in Jakarta Special Province can also be caused by the increasing population throughout the year; the land was needed as a place to live and to meet the necessities of life. Besides, the conversion of agricultural land to nonagricultural land in Jakarta Special Province can also be caused by a large number of industries and factories built to further improve the economy in Jakarta Special Province, as both the capital and the center of the country's economy.

The analysis of population pressure in Jakarta Special Province in the year of 2015, 2020 and 2025 was also done on a regency and city-scale to compare population pressure between each regency and city. Based on table 5 which showed the model I of population pressure in Jakarta Special Province, it can be seen that the population pressure in West Jakarta is the highest. That was because West Jakarta had the highest area of agricultural land among the others. Meanwhile, Central Jakarta and Seribu Islands had the lowest value due to both regions lacking any agricultural land data, so the population pressure for agricultural land cannot be calculated.

Table 3. The model I population pressure per region in 2015, 2020 , and 2025

\begin{tabular}{|l|r|c|r|c|c|c|}
\hline \multirow{2}{*}{\multicolumn{1}{|c|}{ Regency/City }} & \multicolumn{7}{|c|}{ Model I Population Pressure } \\
\cline { 2 - 7 } & 2015 & Class & 2020 & Class & \multicolumn{1}{c|}{2025} & Class \\
\hline Seribu Islands & - & - & - & - & - & - \\
\hline South Jakarta & 999.76 & TP $>1$ & $1,054.82$ & TP $>1$ & $1,112.91$ & TP $>1$ \\
\hline East Jakarta & $1,947.44$ & TP $>1$ & $2,046.76$ & TP $>1$ & $2,151.14$ & TP $>1$ \\
\hline Central Jakarta & - & - & - & - & - & - \\
\hline West Jakarta & $2,942.50$ & TP $>1$ & $3,161.38$ & TP $>1$ & $3,396.53$ & TP $>1$ \\
\hline North Jakarta & 822.25 & TP $>1$ & 869.07 & TP $>1$ & 918.56 & TP $>1$ \\
\hline DKI Jakarta & $7,956.72$ & TP $>1$ & $8,400.36$ & TP $>1$ & $8,868.74$ & TP $>1$ \\
\hline
\end{tabular}

Based on Table 4. and Table 5. the population pressure in Jakarta Special Province using model II and model III can be seen. Both models showed that population pressure continued to increase throughout the years. The value of population pressure using model II resulted better than model III. The low population pressure in Jakarta Special Province (model II) can happen because the calculation was done with adding population income from nonagricultural sectors. The lower value of population pressure in model II also showed the income of the residents in the agricultural and non-agricultural sectors.

Calculation of population pressure in Jakarta Special Province using all three models showed that the value of population pressure in Jakarta Special Province was almost all above one $(\mathrm{TP}>1)$. This meant that the population pressure with the model I in Jakarta Special Province was so high that it is unable to meet the living needs of the population in these areas [20]. This can be caused by the increasing number of residents in Jakarta Special Province from year to year and the conversion of agricultural land to non-agricultural land. Meanwhile, areas with population pressure less than one $(\mathrm{TP}<1)$ meant 
that the area is still able to meet the needs of its population.

The increasing population and decreasing agricultural land will continue to push down the food security of Jakarta Special Province. The impact of land conversion included the disruption of food security, which is one of the goals of national development and changes in food patterns due to the existence of substitute foods [3,21]. Therefore, the government needs to pay attention to this problem by increasing the conversion of agricultural land, carrying out development on lands according to its purpose, and utilizing idle land (land that is temporarily not used). Besides, the government also needs to make an intensification policy in utilizing existing agricultural land [22]. This can be done by making GAPOKTAN so that the intensification and efficiency of agricultural land can be carried out properly.

Table 4. Model II population pressure per region in 2015,

\begin{tabular}{|l|r|c|r|c|c|c|}
\multicolumn{1}{c|}{2020 , and 2025} \\
\cline { 2 - 8 } \multicolumn{1}{|c|}{ Regency/City } & 2015 & Class & 2020 & Class & 2025 & Class \\
\hline Seribu Islands & - & - & - & - & - & - \\
\hline South Jakarta & 649.85 & TP $>1$ & 685.63 & TP $>1$ & 723.39 & TP $>1$ \\
\hline East Jakarta & $1,265.83$ & TP $>1$ & $1,330.39$ & TP $>1$ & $1,398.24$ & TP $>1$ \\
\hline Central Jakarta & - & - & - & - & - & - \\
\hline West Jakarta & $1,912.63$ & TP $>1$ & $2,054.89$ & TP $>1$ & $2,207.75$ & TP $>1$ \\
\hline North Jakarta & 534.46 & TP $>1$ & 564.90 & TP $>1$ & 597.06 & TP $>1$ \\
\hline DKI Jakarta & $5,171.87$ & TP $>1$ & $5,460.24$ & TP $>1$ & $5,764.68$ & TP $>1$ \\
\hline
\end{tabular}

Table 5. Model III population pressure per region in 2015, 2020 , and 2025

\begin{tabular}{|l|c|c|c|c|c|c|}
\hline \multirow{2}{*}{\multicolumn{1}{|c|}{ Regency/City }} & \multicolumn{7}{|c|}{ Model III Population Pressure } \\
\cline { 2 - 8 } & 2015 & Class & 2020 & Class & 2025 & Class \\
\hline Seribu Islands & - & - & - & - & - & - \\
\hline South Jakarta & $1,624.61$ & TP $>1$ & $1,714.08$ & TP $>1$ & $1,808.47$ & TP $>1$ \\
\hline East Jakarta & $3,164.58$ & TP $>1$ & $3,325.98$ & TP $>1$ & $3,495.61$ & TP $>1$ \\
\hline Central Jakarta & - & - & - & - & - & - \\
\hline West Jakarta & $4,781.56$ & TP $>1$ & $5,137.24$ & TP $>1$ & $5,519.37$ & TP $>1$ \\
\hline North Jakarta & $1,336.16$ & TP $>1$ & $1,412.24$ & TP $>1$ & $1,492.66$ & TP $>1$ \\
\hline DKI Jakarta & $12,929.68$ & TP $>1$ & $13,650.59$ & TP $>1$ & $14,411.71$ & TP $>1$ \\
\hline
\end{tabular}

\section{Conclusion}

The conclusion of the analysis of land resources in Jakarta Special Province include:

1. Jakarta Special Province's land-use was dominated by non-agricultural land-use compared to agricultural land-use and the trend showed an increase from 2010 to 2018 . There was a change from 2010 to 2018 with the same pattern for land conversion from dry rice fields, rainfed rice fields, and irrigated rice fields to residential and industrial areas.

2. Spatial and temporal analysis of land carrying capacity in Jakarta Special Province showed static values where both temporal (2000-2019) and spatial (regency/city) results indicated that Jakarta Special Province had a population that exceeded the carrying capacity of its land.

3. The land resource scale in Jakarta Special Province showed that the largest land requirement is for nonagricultural land, namely settlement. Agricultural land-use experienced decreasing.

4. Population pressure on agricultural land-use in Jakarta Special Province showed classification result of TP value being less than 1 from 2015, 2020 to 2025, which indicated that in Jakarta Special Province the population pressure is high enough it is unable to meet the needs of its population.
The authors are thankful for the guidance given by our lecturer in Human Resource \& Economic analysis, Muhammad Arif Fahrudin Alfana, S.Si., M.Sc., Dr. Abdur Rofi', S.Si., M.Si., Dr. RR. Wiwik Puji Mulyani, M.Si., and Dr. Sri Rahayu Budiani, S.Si., M.Si.

\section{References}

1. M. R. Pasimeni, D. Valente, T. Semeraro, I. Petrosillo, and G. Zurlini, in edited by B. B. T.-E. of E. (Second E. Fath (Elsevier, Oxford, 2019), pp. 472-481

2. D. Orrell, Phys. A Stat. Mech. Its Appl. 539, 122928 (2020)

3. R. F. Putri, J. T. SriSumantyo, S. Sukamdi, and R. Harini, Indones. J. Geogr. 51, 364 (2019)

4. T. Y. B. Purba, Indonesia. J. Environ. Educ. Manag. 3, 80 (2018)

5. R. D. Ariani and R. Harini, J. Bumi Indones. 1, (2012)

6. Bidang Tata Ruang dan Lingkungan Hidup. Jakarta, Desain Besar Pertanian Perkotaan Provinsi DKI Jakarta Tahun 2018-2030, Jakarta, (2018)

7. R. F. Putri, M. Naufal, M. Nandini, D. S. Dwiputra, S. Wibirama, and J. T. S. Sumantyo, IOP Conf. Ser. Earth Environ. Sci. 256, 12050 (2019)

8. O. Soemarwoto, Ekologi, Lingkungan Hidup, Dan Pembangunan Djambatan, Bandung, Indonesia, (1985), in Bahasa

9. V. R. B. Moniaga, Agri-Sosioekonomi J. Ilm. Sos. Ekon. Pertan. 7, 61 (2011)

10. M. R. Yunito and L. W. Santosa, J. Bumi Indones. 5, (2016)

11. BPS, Badan Pus. Stat. DKI Jakarta (2019)

12. M. Sun, J. Wang, and K. He, Appl. Geogr. 116, $102170(2020)$

13. M. Yeates, The North American City Harper \& Row Publisher, San Francisco (1980)

14. BPS, Badan Pus. Stat. (2017)

15. R. C. Omar, W. A. Wahab, R. F. Putri, R. Roslan, and I. N. Z. Baharuddin, IOP Conf. Ser. Earth Environ. Sci. 451, 12032 (2020)

16. Dinas PUPR, Profil Kota Tanpa Kumuh Provinsi DKI Jakarta, Jakarta (2017)

17. BPS, Badan Pus. Stat. DKI Jakarta (2018)

18. D. L. Cahya, Procedia - Soc. Behav. Sci. 227, 95 (2016)

19. BPS, Hasil Survei Pertanian Antar Sensus (SUTAS) 2018 Provinsi DKI Jakarta, Jakarta (2018)

20. R. F. Putri, A. Aji, and A. R. Sulistya, IOP Conf. Ser. Earth Environ. Sci. 451, 012020 (2020)

21. N. Fitton, P. Alexander, N. Arnell, B. Bajzelj, K. Calvin, J. Doelman, J. S. Gerber, P. Havlik, T. Hasegawa, M. Herrero, T. Krisztin, H. van Meijl, T. Powell, R. Sands, E. Stehfest, P. C. West, and P. Smith, Glob. Environ. Chang. 58, 101944 (2019)

22. U. Lele and S. W. Stone, Population Pressure, The Environment And Agricultural Intensification Variations On The Boserup Hypothesis, The World Bank, Washington DC (1989) 